\title{
最近の歯学
}

\section{4. 生化学}

\section{リコンビナント BMP（骨形成タンパク質）}

1989 年にこの「最近の歯学」で, 強力な骨誘導物質 である骨形成タンパク質 (Bone Morphogenetic Protein：BMP）の解明が急速に進んでいることを述べ だ)。その後, 単離された遺伝子(cDNA)の解析から, 表 1 に示すよjにBMP. $2 〜 8$ と命名された 7 種類の タンパク質が同定された。これらはすべて構造がよく 似ており, TGF- $\beta$ スーパーファミリーという 1 群の夕 ンパク質に属している。これらの遺伝子からリコンビ ナント BMPが作製され，それを用いて BMPによる 骨誘導の基礎研究と臨床応用が試みられている れわれは培盖七卜歯髄細胞から BMP. 2 遺伝子をク ローニングし、リコンビナント BMPを作製している。 その概略を図 1 に示した。BMP 遺伝子を大腸菌のプ ラスミドに組み込み大量に増幅し，それをさらに動物 細胞用のタンパク質発現ベクター $\mathrm{pSD}(\mathrm{X})$ に移し, チャイニーズ八ムスタ一由来の培養株細胞 ( $\mathrm{CHO}$ cells）に組み込んだ。この細胞からは 2 量体の活性型 BMP が産生される。大腸菌でも大量のリコンビナン ト BMPをつくらせることができるが, BMP の複雑 な高次構造ができず生理活性がない。われわれはさら に活性型 BMP を大量に確保するため, 培養昆虫細胞 とそれに感染するバキュロウィルスを使った系を試み ている。TGF- $\beta$ スーパーファミリーは従来の細胞増殖

表 1

\begin{tabular}{|c|c|}
\hline 骨組織中の BMP & 骨誘導能 \\
\hline BMP-2 (BMP-2 A) & 0 \\
\hline BMP-3 (osteogenin) & \\
\hline BMP-4 (BMP-2 B) & 0 \\
\hline BMP-5 & O \\
\hline BMP-6 (Vgr-1) & \\
\hline $\mathrm{BMP}-7 \quad(\mathrm{OP}-1)$ & 0 \\
\hline BMP-8 (OP-2) & \\
\hline
\end{tabular}

○印はリコンビナントにより骨誘導活性が確認され ているもの。（）は別名
東京医科歯科大学歯学部生化学教室 大井田新一郎

因子とは異なり, 細胞分化誘導の「key regulator」で あると考えられるようになってきた。骨や歯ではこの ファミリーに属するタンパク質が数多く発現してい る。今後リコンビナントタンパク質を用いた研究によ り，硬組織の分化におけるこれらのタンパク質の役割 が明らかになることと思われる。

\section{文献}

1) 大井田新一郎：骨誘導タンパク質 (BMP) の最近 の研究. 口病誌 $56: 397,1989$.

2) 大井田新一郎：骨誘導因子 (BMP と OIF). THE BONE $5: 37-43,1991$.

3）大井田新一郎：BMP 遺伝子の構造とその発現機 構. 歯科ジャ一十ル 38：1024-1032, 1993.

Preparation of recombinant BMP
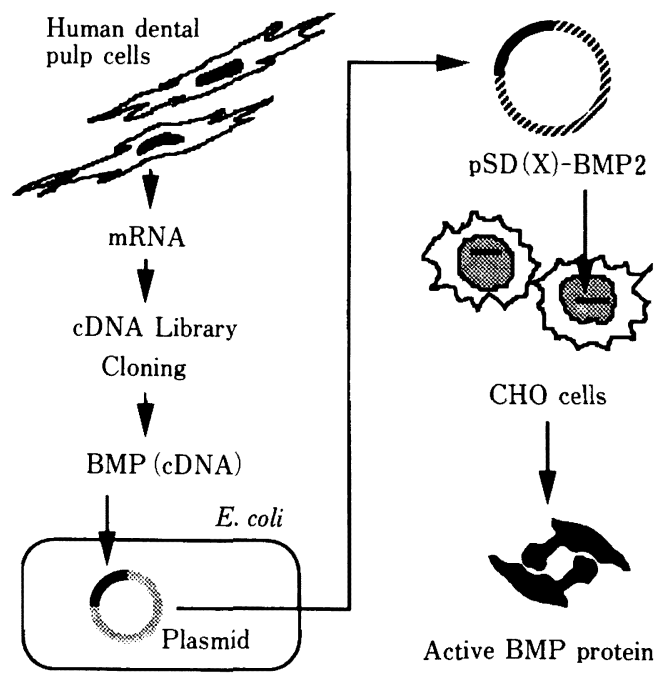

Active BMP protein

図 1 